\title{
Natural radioactivity of coal in the context of radioecological safety and rational use
}

\author{
Iurii N. Pak ${ }^{1 *}$, Dmitrii lu. Pak¹, Zhmagul S. Nuguzhinov¹, Anar lu. Tebaeva1 \\ ${ }^{1}$ Karaganda State Technical University, Karaganda, Republic of Kazakhstan \\ *e-mail:pak_gos@mail.ru
}

\begin{abstract}
Introduction. Environmental contamination with natural radioactive elements is an urgent ecological problem of the coal industry. Radiation hazard associated with natural radionuclides in coals and enclosing rock is a poorly studied problem requiring special attention. Radionuclides and their combustion products in coals, i. e. ash and slag waste and gas aerosol emissions, released into the biosphere, become the sources of pollution. Radiation monitoring is required in the course of geological prospecting, deposits development and rational use.

The research aims to systematize research and analytical material on specific radioactivity of coal and their combustion products, and update the problem of radioecological safety monitoring.

Methodology includes studying data on specific radioactivity of coal at various deposits, studying natural radioactivity of coal, enclosing rock and ash and slag waste, describing ash and slag waste and radon as a source of radioactive contamination, assessing potential radon hazard of mine workings, and analyzing ash composition characteristics for toxicologic estimation of ash dumps and their effect on the environment.

Results. Generalized data on radionuclide concentration in coal burned at the CHP facilities, slag and fly ash are presented. Radionuclide specific concentration is much higher in ash and slag waste of coal heat power industry than in initial coal. It is caused by the radionuclide concentration in the products of coal combustion. Potential hazard of radon released from rock is revealed, and ash composition is characterised for toxicologic estimation of ash dumps.

Conclusions. Uncontrolled coal combustion exacerbates the problem of radioecological safety due to radioactive aerosol emission and the formation of ash and slag waste with increased concentration of natural radionuclides. System monitoring of radioactivity level in the course of geological prospecting, mining, processing and combustion will allow reducing radionuclides entering the fuel cycle and environment.
\end{abstract}

Key words: natural radioactivity; coal; specific radioactivity; radioecological safety; ash and slag waste; radon concentration; microelements.

Introduction. The global economy consumes about 4 billion tons of thermal coal annually. The UNECE Energy Committee's coal working group estimates that coal provides about $27 \%$ of global energy production. In electric power industry, coal is even more important. About 44\% of global electricity is produced with the use of coal.

One of the urgent environmental problems of coal power industry is environmental pollution by natural radioactive elements. According to Iudovich et al. [1] the clarke content of uranium in coal is $3.6 \mathrm{~g} / \mathrm{t}$, and that of thorium for brown coal is $6.3 \mathrm{~g} / \mathrm{t}$, and that for hard coal is $3.5 \mathrm{~g} / \mathrm{t}$. Coal deposits containing uranium in concentrations that significantly exceed (one or two orders of magnitude) the clarke ones are known in many countries of the world: Russia, Kyrgyzstan, Turkey, USA, France, etc.

In the 1940's, attempts were made to use uranium-bearing coals as industrial raw materials for the extraction of uranium. Uranium-coal deposits of Russia, Kazakhstan and 
Kyrgyzstan were the initial mineral resource base of the uranium industry of the USSR [2]. Subsequently, in connection with the discovery of better uranium-containing objects, industrial interest in them fell. Today, uranium coal is considered as a potential source of radioactive pollution of the environment.

Natural radionuclides and specific radioactivity of coal. Table 1 shows the data on coal specific radioactivity at a number of deposits around the world [3-7]. The content of the main radionuclides in coal at various deposits (countries) varies a hundred or more times. In the averaged data across countries, the difference is not significant.

Table 1. Specific radioactivity of coal, $\mathrm{Bq} / \mathrm{kg}$

Таблица 1. Удельная радиоактивность угля, Бк/кг

\begin{tabular}{l|c|c|c}
\hline \multirow{2}{*}{ Basin, country } & \multicolumn{3}{|c}{ Radionuclide } \\
\cline { 2 - 4 } & $\mathrm{U}^{238}$ & $\mathrm{Th}^{232}$ & $\mathrm{~K}^{40}$ \\
\hline \multirow{2}{*}{ In all the world basins in total } & $\frac{20}{15-250}$ & $\frac{20}{7-10}$ & $\frac{50}{37-440}$ \\
The former USSR countries & 28 & 25 & 120 \\
USA & $\frac{18}{1-540}$ & $\frac{21}{2-320}$ & $\frac{52}{1-710}$ \\
Australia & $8.5-47$ & $11-64$ & $23-140$ \\
China & 7 & 16 & 30 \\
Serbia & $18-71$ & $66-122$ & $15.7-220$ \\
Great Britain & 14.2 & $14-52$ & $45-243$ \\
India & $7.8-30$ & $7-19.2$ & $\frac{166}{55-314}$ \\
East Donbass & - & $6-13$ & $147-390$ \\
Urtuisk deposit, Russia & 76 & 21 & 300 \\
& $10-12,300$ & $24-800$ & $2.5-780$
\end{tabular}

According to the UN Scientific Committee on the Effects of Atomic Radiation (SCEAR), the average global concentrations of radionuclides in coal are as follows: $\mathrm{U}^{238}-37 \mathrm{~Bq} / \mathrm{kg} ; \mathrm{Ra}^{226}-35 \mathrm{~Bq} / \mathrm{kg} ; \mathrm{Th}^{232}-30 \mathrm{~Bq} / \mathrm{kg} ; \mathrm{K}^{40}-400 \mathrm{~Bq} / \mathrm{kg}$ [8]. Relatively high levels of natural radionuclides were recorded in a number of coal deposits in the USA, China, Russia and Serbia. Coals of the Urtuisk deposit (Russia), where the abnormal values of specific radioactivity in uranium and thorium reach 12,300 and $800 \mathrm{~Bq} / \mathrm{kg}$, respectively, stand out.

In the USA, in the state of South Dakota, with an annual production of about 1.4 million tons of brown coal, more than 660 tons of $\mathrm{U}^{3} \mathrm{O}^{8}$ were recovered along the way [9]. Specific activity of natural radionuclides of various deposits varies by two, three and more orders of magnitude. For example, the activity of $U^{238}$ varies from 0.6 to $3,600 \mathrm{~Bq} / \mathrm{kg}$ with the average content of $18-28 \mathrm{~Bq} / \mathrm{kg}$.

It was shown that the uranium content in the coal in the fields of Siberia, the Far East, Kazakhstan and Mongolia varies from 0.6 to $32.8 \mathrm{~g} / \mathrm{ton}$, and that of thorium from 0.8 to $32 \mathrm{~g} /$ ton [10].

The events at the Fukushima-1 Japanese nuclear power plant forced the world community to take a fresh look at nuclear safety issues, and some countries announced suspension of the nuclear power plant development program.

Despite the active use of renewable energy sources, the share of coal in the global electricity production in the next two decades will be still significant. Kontorovich 
estimated that coal consumption in the period from 2007 to 2025 will increase by $1.5 \%$ annually.

The most vulnerable spot in coal power industry is the environmental impact made by coal-fired enterprises. The environmental services should focus on such pollutants as sulfur, ash, heavy metals and emissions of these pollutants into the environment when coal is burned at thermal power plants. Radioactive pollution associated with natural radionuclides is of particular interest; it is sometimes underestimated in the present day world. Radioactivity of air and soil in the territory adjacent to the TPP exceeds several times not only background but even maximum permissible values.

The radiation hazard of coal mines associated with natural radionuclides contained in coals and enclosing rocks is one of the most significant and poorly studied problems of the coal industry that requires extreme attention. With the average content uranium in the earth's crust of $2.0 \mathrm{~g} / \mathrm{t}$, the average uranium content in rich ash reaches $400 \mathrm{~g} / \mathrm{t}$. Radionuclides contained in coal with products of their combustion (ash and slag waste and gas-aerosol emissions) enter the biosphere and become a source of radioactive pollution and human exposure. Natural radionuclides from ash dumps can enter the human body through the food chain and when the ash dumps are washed out with water.

The studies have shown that natural radioactivity of the enclosing rock is significantly higher than that of coal. So, gamma-activity of potassium-40 radionuclide reached $1,000 \mathrm{~Bq} / \mathrm{kg}$ in rock, while in coal it did not exceed $100 \mathrm{~Bq} / \mathrm{kg}$.

At the mines of Kuzbass, Ekibastuz, Donetsk, there is no systematic control over the content of radionuclides in rock and mine atmosphere. Meanwhile, specific activity of $\mathrm{U}^{238}$ can range from 3 to $520 \mathrm{~Bq} / \mathrm{kg}$. The content of the remaining natural radionuclides in coal is $2-5$ times lower than that in the enclosing rocks. The $\mathrm{Ra}^{226}$ activity in rock is $20-40 \mathrm{~Bq} / \mathrm{kg}$, and that of $\mathrm{Th}^{232}$ ranges from 30 to $60 \mathrm{~Bq} / \mathrm{kg}$.

Ash and slag waste and radon as sources of radioactive pollution. Coal enterprises are sources of radioactive pollution. Not only the mine personnel is exposed to it, but the population in the nearby area as well. This is caused by the extraction of a significant amount of natural radionuclides from the subsoil alongside with coal. It was shown [11] that in the city of Mezhdurechensk, the Kemerovo region, the gamma background was higher than that in the region as a whole. During a radiometric survey of a number of coal dumps and open pits of building materials, high content of uranium and thorium of $50 \mathrm{~g} / \mathrm{t}$ and $200 \mathrm{~g} / \mathrm{t}$ were recorded. Specific activity of these rocks reached 2,000 Bq/kg. Nevertheless, the waste from the Itatsk open pit is used in the Kemerovo region for road construction.

Radioactivity of the TPP emissions is determined by radioactivity of the initial coal and characteristics of its combustion. In the process of burning coal (burning carbon and removing volatile compounds), radionuclides are concentrated in the combustion products of coal. According to American experts [12], the global total uranium and thorium emissions from coal combustion are about 37,300 tons annually, about 7300 tons coming from the United States.

In brown coals of the Kemerovo region, an increased uranium content of $139 \mathrm{~g} / \mathrm{t}$ was revealed, and in the ash and slag waste generated by the burning of such coal, the uranium content is $902.6 \mathrm{~g} / \mathrm{t}$ [13]. Contamination of ash and slag waste of natural radionuclides at particular Russian TPPs during the combustion of certain coals, for example, near Moscow and Azean, is increased and reaches $520 \mathrm{~Bq} / \mathrm{kg}$ with the standard of uncontrolled use in construction of $370 \mathrm{~Bq} / \mathrm{kg}$.

According to Article 2.1 of the European Union IPPC Directive, Integrated Prevention and Control of Pollution, natural radioactive substances are not subject to the Directive, and emissions of radioactive substances present in most types of fossil fuels are not considered the key environmental issue. It is believed that after combustion of hard coal, brown coal or peat, most radioactive substances remain in the ash [14]. 
In a number of studies, it is noted that the main source of environmental pollution when burning brown coal with a high content of radionuclides is the finely dispersed ash component, fly ash, which is practically not captured by TPP electrostatic precipitators. Table 2 presents generalized data from numerous sources on the ranges of specific radioactivity of various coal burned at thermal power plants and radionuclides in slag and fly ash [14].

When burning German coal, it was found that uranium emission depends on the type of coal, the form of uranium occurrence and the particle size of the ash residue. When burning coal with small contents of uranium and thorium in ash and slag waste used for filling roads and as artificial soils, the radioactive gamma-ray background was exceeded by $2-3$ times in comparison with the local background [15].

Table 2. Radionuclides concentration, $\mathrm{Bq} / \mathrm{kg}$

Таблица 2. Концентрация радионуклидов, Бк/кг

\begin{tabular}{l|c|c|c}
\hline \multicolumn{1}{c|}{ Radionuclide } & Coal & Slag & Fly ash \\
\hline $\mathrm{U}^{238}$ & $9-31$ & $56-185$ & $70-370$ \\
$\mathrm{Ra}^{226}$ & $7-25$ & $20-166$ & $85-281$ \\
$\mathrm{Th}^{232}$ & $9-19$ & 59 & $81-174$ \\
$\mathrm{~K}^{40}$ & $26-130$ & $230-962$ & $233-740$
\end{tabular}

In the process of burning brown coals of the Kansk-Achinsk basin at the Nazarovskaya TPP, it was found that the concentration of uranium in the ash collected from electrostatic precipitators was 2 times, and that of thorium 4 times higher than the initial coal. The main part of uranium in coals is associated with the organic mass of coal and when it is burned, it is released condensing on finely dispersed aerosols, which are largely not captured by electrostatic precipitators. The main part of thorium in coal is, on the contrary, in the mineral component and naturally remains in the ash composition. Since the content of uranium, thorium and potassium-40 in coals in most cases does not exceed the limits of fluctuations of the natural gamma background, the radiation situation mainly depends on the intensity of radon and thoron emission into the mine atmosphere. Radon and thoron are released from the rocks, accumulate in poorly ventilated facilities (mine workings, chambers, mined-out space, niches, etc.). They concentrate the volumetric activity of the decay products of radon, often exceeding the permissible level by tens or even hundreds of times.

The main objects of radiation control that make a significant contribution to the equivalent dose of radiation are as follows:

- the energy of daughter products of radon and thoron in the air of mine workings, industrial and residential premises and in the environment;

- the dose rate of external gamma radiation in the workplaces and in residential premises;

- the content of long-lived radionuclides in the industrial atmosphere, in the soils of agricultural land in drinking water.

The most important task of radiation monitoring is to assess the potential radon hazard of mine workings. This task involves analyzing the actual volumetric activity of radon in the mine atmosphere; studying the relationships between the density of radon flux from the surface of mine workings, groundwater and the volumetric activity of radon in the worked-out space; identifying the basic laws of the process of radon emission from all the sources.

The radon content $\left(\mathrm{T}_{1 / 2}=3.82\right.$ days $)$ in the atmosphere of the Kuzbass mines varies widely, often exceeding the permissible sanitary standards. A significant effect on the 
concentration of radon in the mine atmosphere is exerted by fluctuations in atmospheric pressure. A sharp drop in atmospheric pressure increases radon removal from coal and enclosing rock into the mine workings.

Radon can be used as an indicator gas for detecting spontaneous combustion. Moreover, it becomes possible to evaluate not only the early stage of the process but, taking into account the peculiarities of radon emission from rocks during heating, to evaluate the temperature of the source. Such conclusions can be made, knowing the dynamics of the volumetric activity of radon in the mine atmosphere. Therefore, for the timely detection of spontaneous combustion centers, it is necessary to determine the background content of radon in the air at control points. In mines with a high background concentration of radon in the air, it is necessary to control the radon emission from the mined-out space to the day surface, especially in the areas built up with residential and administrative buildings. In case of exceeding the maximum permissible concentrations of radon, it is necessary to standardize the amount of air supplied to the mine workings with the condition of diluting the radioactive gas to the safe state.

Table 3. The content of trace elements

Таблица 3. Содержание микроэлементов

\begin{tabular}{l|c|c|c|c|c|c}
\hline \multirow{2}{*}{\multicolumn{1}{c|}{ Coal }} & \multicolumn{6}{c}{ Microelements content in fly ash, $\mathrm{mkg} / \mathrm{kW} \cdot \mathrm{h}$} \\
\cline { 2 - 7 } & $\mathrm{Cd}$ & $\mathrm{Co}$ & $\mathrm{Cu}$ & $\mathrm{Ni}$ & $\mathrm{Pb}$ & $\mathrm{Zn}$ \\
\hline Donetsk & 97 & 332 & 955 & 753 & 867 & 614 \\
Kuznetsk & 77 & 109 & 135 & 109 & - & 328 \\
Kansk-Achinsk & 18 & 39 & 29 & 69 & 174 & 145 \\
Ekibastuz & 237 & 1,058 & 638 & 766 & 1,520 & 1,462
\end{tabular}

Microelements and the coal ash composition. Kazakhstan is one of the ten largest coal producers in the world market, ranking third among the CIS countries. About $90 \%$ of Kazakhstan exported coal is Ekibastuz coal. According to Vozzhenikov [16], Ekibastuz coal is generally characterized as weakly radioactive. The clarke content of uranium and thorium is 1.9 and $3.5 \mathrm{~g} / \mathrm{t}$, respectively. High concentration of radionuclides were found in particular coal (areas, seams) of the Karazhyra and Maykubinsk deposits. In general, the deposits of Kazakhstan are poorly surveyed in terms of radionuclides presence and concentration in the initial coal and ash and slag waste [17]. Ekibastuz coal is considered as raw material for complex processing. Ash and overburden of Ekibastuz coal can serve as a parent material for the glass industry. Compounds of silicon and aluminum are raw materials for aluminum production. Coal mining and processing waste is an essential component in cement production, road construction, earthworks, land reclamation, etc. The industrial importance of Ekibastuz coals is the content of scandium $(10.6 \mathrm{~g} / \mathrm{t})$, ytterbium $(2.6 \mathrm{~g} / \mathrm{t})$, hafnium $(8.8 \mathrm{~g} / \mathrm{t})$, cerium $(38.6 \mathrm{~g} / \mathrm{t})$, etc.

The problem of radioecological safety and radiation-hygienic assurance of coal quality must be dealt with from the moment of a coal deposit development. In order to clarify the boundaries of coal with a high content of EPE and classify reserves by their radiation safety, additional exploration of the deposit with the network thickening is needed. A complex of geophysical studies of coal quality control by the radiation and hygiene factor is required: gamma-ray logging at the stages of detailed and operational exploration for prospective and current planning of production by grades; gamma-testing for operational control of mining blocks of coal; gamma-testing in broken rock mass for rational warehousing; gamma-spectrometric studies for element-wise analysis and quality assessment. This specified set of studies will allow certifying consumer coal in the context of radioecological safety and rational use. 
American geochemists Finkelman and Brown note that when accounting the coal mining in the USA, at least half of the arsenic, beryllium, bismuth, cobalt, hafnium, etc. consumed in the country could be obtained annually, while reducing environmental pollution. The data in table 3 presents differentiation of indicators for the content of trace elements in coals of various deposits [18].

A certain environmental impact is exerted not only by the trace elements arising from the burning of coal but also by the ash composition.

Table 4 shows characteristics of the ash fly composition generated during the burning of coal from three deposits used in the largest volume.

Table 4. Coal ash composition

Таблица 4. Состав золы углей

\begin{tabular}{l|c|c|c}
\hline \multirow{2}{*}{ Indicator } & \multicolumn{3}{|c}{ Coal } \\
\cline { 2 - 4 } & Ekibastuz & Kuznetsk & Kansk-Achinsk \\
\hline $\mathrm{SiO}_{2}$ & $57.0-65.0$ & $50.0-64.0$ & $20.3-55.0$ \\
$\mathrm{Al}_{2} \mathrm{O}_{3}$ & $22.0-30.0$ & $18.0-30.0$ & $4.0-13.0$ \\
$\mathrm{Fe}_{2} \mathrm{O}_{3}$ & $2.0-13.0$ & $4.0-15.0$ & $6.0-16.0$ \\
$\mathrm{CaO}$ & $0.3-2.0$ & $2.0-10.0$ & $20.0-46.0$ \\
$\mathrm{MgO}$ & $0.1-1.2$ & $0.5-2.5$ & $3.5-6.0$ \\
$\mathrm{~K}_{2} \mathrm{O}$ & $0.3-1.4$ & $1.3-2.4$ & $0.2-1.1$ \\
$\mathrm{Na}_{2} \mathrm{O}$ & $0.1-0.6$ & $0.5-1.3$ & $0.2-1.1$ \\
$\mathrm{SO}_{3}$ & $0.1-2.0$ & $0.3-2.2$ & $0.9-9.0$
\end{tabular}

These data will allow toxicological assessing ash dumps and their impact on the environment.

Studying the forms of the chemical elements occurrence in coal is important for assessing the conditions of coal formation, studying the behavior of chemical elements during coal burning at thermal power plants and developing the technology of the integrated processing of coal and ash and slag waste. The forms of occurrence of uranium in coal have already been studied for more than half a century. In the middle of the last century, uranium coals were considered as industrial raw materials for uranium extraction $[19,20]$. Subsequently, interest in finding uranium in coal was caused by the potential radioecological hazard associated with the use of coal in the power industry. It was found that the forms of uranium occurrence, alongside with the combustion technology, determine its behavior in the process of using fuel at thermal power plants. Certain experience has been accumulated regarding the forms of the uranium occurrence in various coals. Conflicting information is being viewed. Coals with a lower-clarke uranium content are predominantly characterized by the mineral form, and for coals enriched with uranium by the organic form. The issue of its forms alternation in the process of coal metamorphism and diagenesis remains unclear. Based on the comparison of the uranium content in coal ash and carbohydrate rocks of various deposits in North Asia, it has been concluded that the role of organic matter in the accumulation of uranium for coal is also significant. So, coal ash of different deposits of the Minusinsk basin contains 3-4 times more uranium than carbon-bearing rocks [21].

Art. 275 of the Environmental Code of the Republic of Kazakhstan (RK) of 2019 notes: "Coal can be used for any purpose if the dose limits established by the radiation safety standards are not exceeded. Coal with radioactivity above the levels stipulated by the applicable radiation safety standards and sanitary rules is subject to storage and burial in the internal dump of the open pit, subject to compliance with radiation safety standards". 
The radiation hazard standards for solid fuel ash are defined in the Technical Regulation "Requirements for safety of coal and production processes for their extraction, processing, storage and transportation", approved by the Government of the Republic of Kazakhstan in 2010 (table 5).

Table 5. Radiation hazard standards of solid fuel ash

Таблица 5. Нормы радиационной опасности золы твердого топлива

\begin{tabular}{c|c|c}
\hline $\begin{array}{c}\text { Radiation } \\
\text { hazard class }\end{array}$ & $\begin{array}{c}\text { Radionuclide effective } \\
\text { activity in ash, Bq/kg }\end{array}$ & \multicolumn{1}{c}{ Conditions of the ash safe use } \\
\hline I & $<370$ & $\begin{array}{l}\text { Ash can be used in residential and public buildings under } \\
\text { construction and reconstruction } \\
\text { Ash can be used in road construction within the territory of } \\
\text { settlements and areas of prospective development, as well as } \\
\text { in the construction of industrial facilities } \\
\text { Ash can be used in road construction outside settlements } \\
\text { III }\end{array}$ \\
IV & $\begin{array}{c}\text { The issue of ash use is resolved in each case separately by } \\
\text { agreement with the territorial bodies of the State Sanitary } \\
\text { and Epidemiological Service of the Republic of Kazakhstan }\end{array}$ \\
\hline
\end{tabular}

This technical regulation does not solve the problem of the geoecological hazard of extracting and burning fuels containing natural radionuclides. With the ongoing uncontrolled burning of coal, the issues of radioecological safety remain unresolved. This problem requires a centralized approach.

Conclusion. Extraction of coal and enclosing rocks containing natural radionuclides from the subsoil inevitably leads to radioactive pollution of the environment. This is mainly caused by the release of radioactive aerosols and the formation of ash and slag waste with increased concentration of natural radionuclides in the process of burning fuel at the enterprises of the coal-fuel industry. In most countries, the processes of extracting and processing coal with increased radionuclide contents are not regulated. It is necessary to monitor systematically the level of radioactivity during geological exploration, development of deposits and rational use of coal, which will minimize the ingress of radionuclides into the fuel cycle and into the environment.

\section{REFERENCES}

1. Iudovich Ia. E., Ketris M. P., Merts A. V. Impurity elements in mineral coal. Leningrad: Nauka Pubishing; 1985. (In Russ.)

2. Sidorova G. P., Krylov D. A. Coal and ash slag waste radioactivity at coal-fired electric power plants. Energiia: ekonomika, tekhnika, ekologiia = Energy: Economy, Engineering, and Ecology. 2017; 2: 21-26. (In Russ.)

3. Bouska V. Int. J. Coal Geol. 1999; 40 (2-3): 211.

4. Shpirt M. Ia., Rashevskii V. V. Forms of compounds and the behavior of microelements in the cource of fossil fuel processing. Moscow: Kulikovo pole Publishing; 2010. (In Russ.)

5. Jankovic M. M., Todorovic D. J., Nikolic J. D. Analysis of Natural Radionuclides in Coal, Slag and Ash in Coal - Fired Power Plants in Serbia. Journal of Mining and Metallurgy. 2011; 47: 149-155.

6. Suhana J., Mohd R. Analysis of Natural Radioactivity in Coal and Ashes from a Coal Fired Power Plant. Chemical Engineering Transactions. 2015; 45: 1549-1554.

7. Xinwei Lu, Xiaodan Jia and Fengling Wang. Natural Radioactivity of Coal and its by-products in the Baoji Coal-fired Power Plant. China-Current science. 2006; 91 (11): 1508-1511.

8. UNSCEAR. United Nations Scientific Committee on the Effects of Atomic Radiation. Sources and Effects of Ionizing Radiation. New York; 2000. P. 40-75.

9. Iudovich Ia. S. A gram which is more expensive than a ton: Rare elements in cloal. Moscow: Nedra Publishing; 1989. (In Russ.)

10. Arbuzov S. I., Volostnov A. V., Mashenkin V. S. Radiogeochemical characteristic of coal of North Asia. Energetik = Power and Electrical Engineering. 2010; 3: 2-8. (In Russ.)

11. Aluker N. L., Vasiliev I. A., Eremenko A. N., Nechaev A. F. The problem of radiation safety in coal industry. In: Environmental problems of coal mining in the region when switching to sustainable development: Proc. Int. sci.-to-pract. conf. Vol. 2. Kemerovo: Kuzbassvuzizdat Publishing; 1999. P. 139-149. (In Russ.) 
12. Richard Rhodes, Denis Beller. The need for nuclear power. Biulleten MAGATE =IAEA Bulletin. 2000; 42 (2): 43-50.

13. Nifantov B. F., Zaostrovskii A. N., Zanina O. P. Mining-geological and technological significance of prescious and toxic elements distribution in the Kuznetsk coal. Ugol = Coal. 2009; 12: 59-61. (In Russ.)

14. Ovseichuk V. A., Krylov D. A., Sidorova G. P. Radioactivity of coal and their combustion products. Atomnaia strategiia $=$ Nuclear Strategy. 2013; 3: 12-14. (In Russ.)

15. Rikhvanov L. P., Ershov V. V., Arbuzov S. I. Integrated ecological and geochemical survey of coal. Ugol = Coal. 1998; 2: 54-57. (In Russ.)

16. Vozzhenikov G. S. Natural radioactivity of Ekibastuz coal and their ash residue. Izvestiya vysshikh uchebnykh zavedenii. Gornyi zhurnal = News of the Higher Institutions. Mining Journal. 1992; 5: 1-6. (In Russ.)

17. Pak Iu., Pak D. Iu., Ponomareva M. V., Baizbaev M. B., Zhelaeva N. V. Radioactivity of coal and its comdustion wastes. Coke and Chemistry. 2018; 61 (5): 188-192.

18. Kropp L. I., Styrikovich M. A., Khorkov A. V. Thermal coal use and ecological standards. Teploenergetika $=$ Thermal Engineering. 1997; 2: 7-12. (In Russ.)

19. Breges J. A., Deul M., Rubinstein S. Geochemistry and mineralogy of a uraniferous lignite. Economic Geology. 1955; 50 (2): 206-226.

20. Vine J. D. Uranium-bearing coal in the United States. In: Proc. International Conf. on the Peaceful Use of Atomic Energy. Jeneve, 8-20 August 1955. Vol. 6. Geology of Uranium and Thorium. 1955, p. 525-531.

21. Arbuzov S. I., Ershov V. V. Geochemistry of rare elements in Siberian coal. Tomsk: D-Print Publishing; 2007. (In Russ.)

Received 8 October 2020

\section{Information about authors:}

Iurii N. Pak - DSc (Engineering), Professor, Head of the Educational and Methodological Association of Universities of the Republic of Kazakhstan, Karaganda Technical University. E-mail: pak_gos@mail.ru Dmitrii Iu. Pak - PhD (Engineering), Associate Professor, associate professor of the Department of Geology and Exploration of Mineral Deposits, Karaganda Technical University. E-mail: pak kargtu@mail.ru

Zhmagul S. Nuguzhinov - DSc (Engineering), Professor, Director of Kazakh Multiprofile Institute of Reconstruction and Development (KazMIRD) of Karaganda Technical University. E-mail: kazmirr@mail.ru Anar Iu. Tebaeva - MS, lecturer, Department of Geology and Exploration of Mineral Deposits, Karaganda Technical University. E-mail: anara.tebaeva@gmail.com

\section{Природная радиоактивность угля в контексте радиоэкологической безопасности и рационального использования}

Пак Ю. Н. ${ }^{1}$, Пак Д. Ю. ${ }^{1}$, Нугужинов Ж. С. ${ }^{1}$, Тебаева А. Ю. ${ }^{1}$

${ }^{1}$ Карагандинский государственный технический университет, Караганда, Республика Казахстан.

\section{Peфepam}

Введение. Одной из актуальных экологических проблем угольной отрасли является загрязнение окружающей среды естественными радиоактивными элементами. Радиационная опасность, связанная с естественными радионуклидами, содержащиимся в углях и вмещающчих породах одна из малоизученных проблем, требующих особого внимания. Содержащиеся в углях радионуклиды с продуктами их сжигания (золошлаковые отходы и газоаэрозольные выбросы), попадая в биосферу, становятся источниками загрязнения окружающей среды. Нужен мониторинг уровня радиоактивности при проведении геологоразведочных работ, отработке месторождений и рачиональном использовании отвалов.

Целью работы является систематизация исследовательских и аналитических материалов об удельной радиоактивности углей и продуктов их сжигания и актуализация проблемь мониторинга радиоэкологической безопасности.

Методика исследований. Изучение данных об удельной радиоактивности углей различных месторождений. Исследование естественной радиоактивности углей, вмещуающих пород и золошлаковых отходов. Рассмотрение золошлаковых отходов и радона как источника радиоактивного загрязнения и оценка потенциильной радоноопасности горных выработок. Анализ характеристик состава золь для токсикологической оченки золоотвалов и их влияния на окружаюшую среду.

Результаты. Приведены обобщенные данные о конщентрации радионуклидов в различных углях, сжигаемых ТЭС, шлаках и летучей золе. В золошлаковых отходах угольной теплоэнергетики удельная кониентрачия радионуклидов значительно выше, чем в исходных углях, что вызвано концентрированием радионуклидов в продуктах сгорания угля. Обозначена потенциальная 
опасность радона, освобождаемого из горных пород, дана характеристика состава золь для токсикологической оценки золоотвалов.

Выводы. Бесконтрольное сжигание угля усугубляет проблему радиоэкологической безопасности за счет выбросов радиоактивных аэрозолей и образования золошлаковых отходов с повышенными концентрациями естественных радионуклидов. Системный мониторинг уровня радиоактивности в прочессе геологической разведки, добычи, переработки и сжигания позволит минимизировать попадание радионуклидов в топливный цикл и окружающую природную среду.

Ключевые слова: естественная радиоактивность; уголь; удельная радиоактивность; радиоэкологическая безопасность; золошлаковые отходы; концентрация радона; микроэлементы.

\section{БИБЛИОГРАФИЧЕСКИЙ СПИСОК}

1. Юдович Я. Э., Кетрис М. П., Мерц А. В. Элементы-примеси в ископаемых углях. Л.: Наука, 1985. 239 с.

2. Сидорова Г. П., Крылов Д. А. Радиоактивность углей и золошлаковых отходов угольных электростанций // Энергия: экономика, техника, экология. 2017. № 2. С. 21-26.

3. Bouska V. // Int. J. Coal Geol. 1999. Vol. 40. No. 2-3. P. 211.

4. Шпирт М. Я., Рашевский В. В, Формы соединений и поведение микроэлементов в процессах переработки горючих ископаемых. М.: Куликово поле, 2010. 384 с.

5. Jankovic M. M., Todorovic D. J., Nikolic J. D. Analysis of natural radionuclides in coal, slag and ash in coal - fired power plants in Serbia // Journal of Mining and Metallurgy. 2011. Vol. 47. P. 149-155.

6. Suhana J., Mohd R. Analysis of natural radioactivity in coal and ashes from a Coal Fired Power Plant // Chemical Engineering Transactions. 2015. Vol. 45. P. 1549-1554.

7. Lu Xi., Jia X. and Wang F. Natural Radioactivity of Coal and its by-products in the Baoji Coal-fired Power Plant // China - Current science. 2006. Vol. 91. No. 11. P. 1508-1511.

8. UNSCEAR. United Nations Scientific Committee on the Effects of Atomic Radiation // Sources and Effects of Ionizing Radiation. New York, 2000. P. 40-75.

9. Юдович Я. С. Грамм дороже тонны: редкие элементы в углях. М.: Недра, 1989. 160 с.

10. Арбузов С. И., Волостнов А. В., Машенькин В. С. Радиогеохимическая характеристика углей Северной Азии // Энергетик. 2010. № 3. С. 2-8.

11. Алукер Н. Л., Васильев И. А., Еременко А. Н., Нечаев А. Ф. Проблема радиационной безопасности угольной отрасли // Экологические проблемы угледобывающей отрасли в регионе при переходе к устойчивому развитию: тр. Междунар. науч.-практ. конф. Т. 2. Кемерово: Кузбассвузиздат, 1999. С. 139-149.

12. Родс Р., Беллер Д. Потребность в ядерной энергии. Взгляд на трудное энергетическое будущее мира // Бюллетень МАГАТЭ. 2000. Т. 42. № 2. С. 43-50.

13. Нифантов Б. Ф., Заостровский А. Н., Занина О. П. Горно-геологическое и технологическое значение распределения ценных и токсичных элементов в Кузнецких углях // Уголь. 2009. № 12. С. 59-61.

14. Овсейчук В. А., Крылов Д. А., Сидорова Г. П. Радиоактивность углей и продуктов их сжигания // Атомная стратегия. 2013. № 3. С. 12-14.

15. Рихванов Л. П., Ершов В. В., Арбузов С. И. Комплексное эколого-геохимическое исследование углей // Уголь. 1998. № 2. С. 54-57.

16. Возжеников Г. С. Естественная радиоактивность Экибастузских углей и их зольных остатков // Известия вузов. Горный журнал. 1992. № 5. С. 1-6.

17. Pak Yu., Pak D. Yu., Ponomareva M. V., Baizbayev M. B., Zhelayeva N. V. Radioactivity of coal and its comdustion wastes // Coke and Chemistry. 2018. Vol. 61. No. 5. P. 188-192.

18. Кропп Л. И., Стырикович М. А., Хорьков А. В. Использование энергетических углей и экологические стандарты // Теплоэнергетика. 1997. № 2. С. 7-12.

19. Breges J. A., Deul M., Rubinstein S. Geochemistry and mineralogy of a uraniferrous lignite // Economic Geology. 1955. Vol. 50. No. 2. P. 206-226.

20. Вайн Дж. Д. Урансодержащие угли в США // Матер. Междунар. конф. по мирному использованию атомной энергии. Женева, 8-20 августа 1955. Т. 6. Геология урана и тория. Женева, 1955. C. 525-531.

21. Арбузов С. И., Ершов В. В. Геохимия редких элементов в углях Сибири. Томск: Д-Принт, 2007. $468 \mathrm{c}$.

Поступила в редакцию 8 октября 2020 года

\section{Сведения об авторах:}

Пак Юрий Николаевич - доктор технических наук, профессор, руководитель Учебнометодического объединения вузов Республики Казахстан, Карагандинский технический университет. E-mail: pak_gos@mail.ru

Пак Дмитрий Юрьевич - кандидат технических наук, доцент, доцент кафедры геологии и разведки месторождений полезных ископаемых Карагандинского технического университета. E-mail: pak_kargtu@mail.ru 
Нугужинов Жмагул Смагулович - доктор технических наук, профессор, директор Казахского многопрофильного института реконструкции и развития (КазМИРР) при Карагандинском техническом университете. E-mail: kazmirr@mail.ru

Тебаева Анар Юлаевна - магистр, преподаватель кафедры геологии и разведки месторождений полезных ископаемых Карагандинского технического университета. E-mail: anara.tebaeva@gmail.com

Для цитирования: Пак Ю. Н., Пак Д. Ю., Нугужинов Ж. С., Тебаева А. Ю. Природная радиоактивность угля в контексте радиоэкологической безопасности и рационального использования // Известия вузов. Горный журнал. 2021. № 1. C. 97-106 (In Eng.). DOI: 10.21440/05361028-2021-1-97-106

For citation: Pak Iu. N., Pak D. Iu., Nuguzhinov Zh. S., Tebaeva A. Iu. Natural radioactivity of coal in the context of radioecological safety and rational use. Izvestiya vysshikh uchebnykh zavedenii. Gornyi zhurnal = News of the Higher Institutions. Mining Journal. 2021; 1: 97-106. DOI: 10.21440/0536-1028-2021-1-97-106 